\title{
TRAFFIC VIOLATIONS: VICARIOUS LIABILITY OF OWNERS AND PRESUMPTIVE OWNER- OPERATION
}

Habitual observance of traffic laws ${ }^{1}$ undoubtedly depends to a significant degree on large-scale prosecution of violators. At the same time, respect for the law requires the presence of safeguards against the punishment of innocent defendants. ${ }^{2}$ Efforts toward more efficient means of enforcement must take account of due process and its judicially inferred requirements: the presence of "fault" 3 and a rational connection between proven and presumed facts. ${ }^{4}$ Attempts to mitigate the prosecution's traditional burdens regarding the identity of the traffic law violator have sometimes been defeated by the rigorous application of these limitations.

In the past the problem of identification has been particularly acute in parking offenses, where the violator is apt not to be present at the time of detection. The introduction of parking meters multiplied the number of violations, thus aggravating the problem. Alternative solutions have been attempted: ordinances making the owner liable for all parking offenses involving his

${ }^{1}$ Traffic laws may be grouped with those statutory offenses which omit the requirement of mens rea and thus are considered somewhat distinct from the larger body of the criminal law. This class of offenses is generally termed "public welfare" offenses. Consult Sayre, Public Welfare Offenses, 33 Col. L. Rev. 55 (1933).

Although the weight of authority is that prosecution for violation of a municipal ordinance is in the nature of a civil action for recovery of a "debt," the action is sometimes regarded as criminal, especially where the offense constitutes a misdemeanor under the laws of the state. Consult $9 \mathrm{McQuillin}$, The Law of Municipal Corporations $\$ 27.06$ (3d ed., 1950); The Violation of a Municipal Ordinance as a Crime, 1 Vand. L. Rev. 262 (1948); Public Torts, 35 Harv. L. Rev. 462 (1922).

In characterizing traffic offenses the governing New York statute says: "A traffic infraction is not a crime, and the penalty or punishment imposed therefor shall not be deemed for any purpose a penal or criminal penalty or punishment, and shall not affect or impair the credibility as a witness, or otherwise, of any person convicted thereof. . . . [A]Il provisions of law relating to misdemeanors ... except as herein otherwise expressly provided shall apply to traffic infractions, except however, that no jury trial shall be allowed for traffic infractions." N.Y. Vehicle and Traffic Law (McKinney, Supp., 1955) $\$ 2$ (29).

${ }^{2}$ This consideration should not be minimized by the slightness of penalties for most traffic offenses. For an exhaustive study of penalties, consult Warren, Traffic Courts, c. XI (1942). Since the penalties are small relative to the effort and expense of appeal, adequate safeguards against abuse and incompetence at the enforcement level are peculiarly important. Consult Warren, ibid., for a comprehensive development of this thesis. The paucity of appellate cases involving traffic offenses should suggest nothing regarding the adjudicatory performance at the trial level. (According to Warren, ibid., at 78, the percentage is something less than one half of one per cent).

${ }^{3}$ Fault is used herein in its broadest sense to denote some significant connection between the criminal defendant and the prohibited activity. Thus, with regard to strict criminal liability Morissette v. United States, 342 U.S. 246, 256 (1952) states: "The accused, if he does not will the violation, usually is in a position to prevent it. . .."

"Tot v. United States, 319 U.S. 463 (1943), is the leading case expounding the "rational connection" standard. 
car; and legislative or judicial presumptions of parking by the owner of the illegally parked car. ${ }^{5}$

In People v. Hildebrandt, ${ }^{\circ}$ a recent New York prosecution for speeding which was appealed to that state's highest court, the state relied on a set of "phototraffic" camera shots" which accurately revealed the speed of the defendant's car and, unlike radar, served as a check on the patrolman's record of the license number. ${ }^{8}$ The court of appeals reversed the conviction on the ground that the state had failed to carry its burden of proving that the defendant had been driving his car at the time of the offense. The court refused to extend to speeding violations the rebuttable judicial presumption of owneroperation which it had previously sanctioned in connection with parking violations. ${ }^{9}$

The mechanical device used in the Hildebrandt case reduces the danger of human error in detection of speeding offenses to the point where it is substantially the same as in parking violations. Also, as was true with the parking problem, more efficient prosecution of speeding offenders can be realized by eliminating, for practical purposes, ${ }^{10}$ the need for direct proof of operation. In view of these close similarities, this comment will examine whether either or both of the solutions adopted to meet the problem of identification in parking infractions might constitutionally be applied to speeding offenses. ${ }^{11}$

5These solutions are treated in Parts I and II, respectively, of this comment.

6 308 N.Y. 397,126 N.E. 2 d 377 (1955).

T The photographic speed recorder is not a recent invention. See Commonwealth v. Buxton, 205 Mass. 49, 91 N.E. 128 (1910). The camera involved in the Hildebrandt case takes two side-view photographs of the moving car a set time interval apart. By reference to a fixed object in the background one can measure the distance travelled by the car during the interval of .0568 seconds; under this time interval, the number of inches the car travels is equal to the speed of the car in miles per hour. From personal correspondence with Traffic Controls, Inc., Rochester 2, N.Y., on file at the editorial offices of U. of Chi. L. Rev.

${ }^{8}$ The photographs will reveal an error except for the remote possibility that a license number erroneously recorded by a patrolman belongs to a car of the same make, model, year and general coloration.

- People v. Rubin, 284 N.Y. 392, 31 N.E. 2d 501 (1940). For an extensive discussion of the Hildebrandt case consult text at 539 infra.

${ }^{10}$ Though the defendant owner may of course come forward with evidence to rebut an owner-operator presumption, in the great majority of violations the owner will either have been the driver or the driver will be revealed when the owner attempts to rebut the presumption.

${ }^{11}$ After the decision in the Hildebrandt case, the New York Association of Chiefs of Police recommended a bill providing for a statutory presumption of owner-operation in all traffic offenses. Also, it appears that the same "phototraffic" camera device is being introduced in other states. From correspondence with Traffic Controls, Inc., Rochester 2, N.Y., on file at the editorial offices of the U. of Chi. L. Rev.

Recently an appellate court of New York was first confronted with the question of whether a radar timing device reading was competent evidence to support a conviction for speeding. The court ruled that the state had not carried its burden of establishing the accu- 


\section{Vicarious Liability of Owners}

The most direct method of solving the problem of identification in parking infractions is represented by a Boston regulation which made it an offense for anyone to "allow, permit or suffer any vehicle registered in his name to stand, or park in any street ... under the control of the city in violation of any of the rules and regulations of the Traffic Commission of the City of Boston."12 [Italics added.] In Commonrealth v. Ober ${ }^{13}$ the Supreme Judicial Court of Massachusetts interpreted this regulation as making the owner strictly liable ${ }^{14}$ for all parking offenses involving his car and upheld the imposition of such liability. ${ }^{15}$ However, the same statutory language has been interpreted by another court to require proof of guilty knowledge ${ }^{16}$ and still another court gave similar language only prima facie effect. ${ }^{17}$ The Ober court was criticized at the time for failing to give adequate attention to the vicarious nature of the liability it upheld, ${ }^{18}$ although it did make passing reference to cases involving a master's criminal liability for his servant's acts. ${ }^{10}$

racy of the instrument. The wide use in New York of scientific traffic devices was noted, but the court cautioned that science "must not bring push-button justice unless and except such justice is surrounded by the long established rules of evidence." People v. Offerman, 204 Misc. 769, 774-75, 125 N.X.S. 2d 179, 185 (S. Ct., 1953). The court then suggested that the legislature establish a presumption of accuracy in the radar reading.

${ }^{12}$ Quoted in Commonwealth v. Ober, 286 Mass. 25, 26-27, 189 N.E. 601 (1934).

${ }^{23}$ Ibid.

${ }^{14}$ But see ibid., at 32,604 , where the court said: "The reported evidence established a prima facie case which was not met by evidence offered by the defendant." In People v. Rubin, 284 N.Y. 392, 397, 31 N.E. 2d 501, 503 (1940), the Ober case was cited for the proposition that it was competent to conclude from proof of ownership that the defendant "controlled" the car.

15 "[T]his is one of the unusual instances where a person at his peril must see to it that the rules and regulations are not violated by his act or by the act of another." (Italics added.) Commonwealth v. Ober, 286 Mass. 25, 32, 189 N.E. 601, 604 (1934).

${ }^{16}$ People v. Forbath, 5 Cal. App. 2d 767, 42 P. 2d 108 (Super. Ct., 1935). The Massachusetts court said that the legislature, "legislating for the common welfare, has put the burden upon the individual of ascertaining at his peril whether his conduct is within the scope of the criminal prohibition." Commonwealth v. Ober, 286 Mass. 25, 31, 189 N.E. 601, 603 (1934). The California court could not say "that the law "has put the burden upon the individual of ascertaining (and controlling) at his peril' his conduct and the conduct of others, out of his presence, without his knowledge, and over whom he has no control, "within the scope of the criminal prohibition." (Italics added.) People v. Forbath, supra, at 722,110 . In other words, the burden of criminal liability must be coincident with the owner's conduct.

${ }^{17}$ Chicago v. Crane, 319 Ill. App. 623, 49 N.E. 2d 802 (1943).

${ }_{18}$ 'To divest the words 'allow,' 'permit' and 'suffer,' as used in the ordinance, of their implication of knowledge and intent, would not only destroy the union of act and intent but would create a crime possessing neither of such elements." People v. Forbath, 5 Cal. App. 2d 767, 770, 42 P. 2d 108, 109 (Super. Ct., 1935). Consult also 14 B. U. L. Rev. 672 (1934), and 33 Mich. L. Rev. 443, 1231 (1935), both noting Commonwealth v. Ober, 286 Mass. 25, 189 N.E. 601 (1934).

${ }^{19}$ Commonwealth v. Ober, 286 Mass. 25, 31-32, 189 N.E. 601, 603 (1934). 
It has been recognized that the principal justification for the imposition of criminal liability for the acts of another lies in its potential deterrent effect. ${ }^{20}$ Thus, vicarious liability will be permitted only where the relation between the defendant and the primary wrong-doer is such that the former has substantial power to check the latter's activity. ${ }^{21}$ And, assuming such control, liability should be imposed only if the public interest to be served is sufficiently important to require the defendant to take the necessary precautions.22 Finally, since the test of due process is one of reasonableness, the gravity of the penalty relative to the fault involved and the public interest to be served should be a factor bearing on the imposition of vicarious criminal liability. ${ }^{23}$ These three considerations should dictate the limits of such liability.

The frontier of vicarious criminal liability is represented by certain successful prosecutions for the sale of liquor to minors ${ }^{24}$ and for violations of the federal Food and Drug Act $^{25}$ where the defendant neither committed the proscribed act nor possessed knowledge of its commission or could be said to have

${ }^{20}$ Sayre, Criminal Responsibility for the Acts of Another, 43 Harv. L. Rev. 689, 722 (1930). Note that some courts reject any type of vicarious liability. Ibid., at 714 .

${ }^{21}$ Ibid., at 703-4, collecting American cases; Edwards, Mens Rea in Statutory Offenses 235-38 (1955), discussing English authorities. Some courts require not only "control," but knowledge or acquiescence by the party sought to be charged with vicarious criminal liability. Consult cases cited in note 24 infra.

The "public welfare" offenses, where criminal liability is imposed upon one who commits the proscribed acts, without regard to any guilty knowledge, similarly require a power to prevent. Thus, where the defendant could not within reason avoid doing the prohibited acts, the statute making such activity a crime is unconstitutional. E.g., Commonwealth v. O'Harrah, 262 S.W. 2 d 385 (Ky., 1953). Rather, the "public welfare" offenses involve "neglect where the law requires care.... The accused, if he does not will the violation, usually is in a position to prevent it. . . " Morissette v. United States, 342 U.S. 246, 255-56 (1952).

2 Sayre has urged that even where the penalty is very slight, strict criminal liability is justified only "if adequate enforcement depends upon wholesale prosecutions or if the social danger arising from the violation is serious. ..." Sayre, Public Welfare Offenses, 33 Col. L. Rev. 55, 78 (1933).

${ }^{2}$ It is Sayre's position that only in the area of "petty misdemeanors involving no moral delinquency where the penalty is no more than a slight fine and public policy so requires, [is the imposition of vicarious liability justified without requiring] proof of actual authorization or knowledge. ..." Sayre, op. cit. supra note 20 , at 723. Unreasonable and oppressive statutory penalties will be considered a deprivation of property without due process of law. E.g., Southwestern Tel. \& Tel. Co. v. Danaher, 238 U.S. 482 (1915).

24 Numerous state courts have held that it is not unconstitutional to make the licensee punishable for his employees' illegal sale of intoxicating liquor to a minor, even though the sale was made without the employer's consent or knowledge and against his bona fide instructions; but there are just as many cases contra. Consult Criminal Responsibility of One Authorized Generally To Sell Intoxicating Liquors for Particular Illegal Sale Thereof by Employee or Agent, 139 A.L.R. 306 (1942).

${ }^{25} 34$ Stat. 768 (1906), as amended, 21 U.S.C. $\$ 1$ et seq. (1953). For example, in United States v. Dotterweich, 320 U.S. 277 (1943), noted in 19 Ind. L.J. 265 (1944), the convicted defendant was a corporate officer who had no knowledge of the subordinate employee's introduction of adulterated food into interstate commerce. Four members of the Supreme Court dissented. 
acquiesced therein. In this class of cases the justification for the imposition of vicarious liability lies in the control implicit in the employment relationship, which allows the master opportunity to evaluate his servant's conduct and to press upon the latter the necessity for extraordinary care. ${ }^{26}$ Here it is not unreasonable to assume that punishment of the owner may serve as some check on the wrongful activity of another. ${ }^{27}$

These principles would seem to justify the imposition of vicarious liability for parking violations where the bailee's operation of the owner's vehicle is of the essence of the relationship between the two parties, as where the bailee is a chauffeur or delivery man. Less clearly, vicarious liability might be upheld where the bailment is but an incident of the relationship, provided that the relationship allows for constant supervision and that punishment of the owner would probably deter wrong-doing, as in the family or ordinary employment situation. However, where the only "control" which exists is that inherent in the power to refuse bailment (or in the fact that the owner could accompany the bailee), vicarious liability would certainly represent a stretch of precedent. Here it may be doubted whether any appreciable public interest would be served by punishing the owner for the offense of the bailee. Legislation could be provided, of course, which differentiates these "control" situations, but such differentiation would reintroduce the problem of operatoridentification.

With regard to parking infractions, the peculiar difficulties of identification and the relative slightness of the penalty ${ }^{28}$ represent strong reasons for upholding vicarious liability, at least in the control situations analogous to the "frontier" cases. However, the fact that legislation similar to that involved in the Ober case has been interpreted by the judiciary of other states so as to avoid the result of vicarious liability ${ }^{29}$ suggests that these reasons have not been controlling.

Since the Ober case probably does represent a deviation from the generally

${ }^{\Re}$ But cf. United States v. Parfait Powder Puff Co., 163 F. 2d 1008 (C.A. 7th, 1947), where the distributor was penalized for introducing into interstate commerce articles which, without his knowledge, had been aduiterated by the manufacturer.

${ }^{27}$ From the legislative standpoint another practical justification for punishing the owner may be said to lie in the difficulties of identifying the primary wrongdoer, although this consideration is in a sense at variance with the judicial rationale of control.

${ }^{2}$ For examples of penalties in traffic offenses, consult note 30 infra. In United States v. Dotterweich, 320 U.S. 277 (1943), stated in note 25 supra, the defendant was fined $\$ 500$ on each of three counts with payment suspended under the second and third counts. (United States v. Buffalo Pharmacal Co., 131 F. 2d 500, 501 [C.A. 2d, 1940]). The Food and Drug Act prescribed a maximum penalty of $\$ 1,000$ and one year's imprisonment. 52 Stat. 1043, 21 U.S.C. $\$ 333$ (1953). In State v. Erlandson, 126 Mont. 316, 249 P. 2d 794 (1952), the court sustained a judgment and fine of $\$ 250$ against a tavern owner although the agent's sale to a minor was without the owner's knowledge. The statute provided for penalties of $\$ 100$ to $\$ 500$ and imprisonment for thirty days to six months. Ibid., at 318,795 .

${ }^{20}$ Cases cited notes 16 and 17 supra. 
recognized limits of vicarious "criminal" liability, it is believed that the courts uniformly would refuse to sanction vicarious liability in offenses as serious as speeding. The owner's degree of control-however that concept be definedis of course the same whether the offense be illegal parking or speeding; and the public interest in the need for elimination of the necessity for operatoridentification is from at least one standpoint stronger in speeding offenses because of the greater attendant social dangers. However, the peculiar difficulties of identification in the parking situation are not present in speeding offenses. In addition, the difference in possible penalties alone may well undercut what precedent value the Ober case would otherwise have. ${ }^{30}$

Some support for the above conclusion can be found in the judicial reaction to Ontario legislation ${ }^{32}$ which purported to make the car owner vicariously liable for a large class of traffic offenses unless the owner could prove that his vehicle was used without permission. ${ }^{32}$ It appears that the Ontario courts

\footnotetext{
${ }^{30}$ For penalties consult Warren, Traffic Courts, c. XI (1942). In New York, violators of municipal parking ordinances concerning public streets or highways (but not including highways maintained by the state) are punishable by a fine not exceeding $\$ 10$ for the first offense, and $\$ 10$ to $\$ 25$ or imprisonment for not less than two or more than fifteen days for the second offense. Any third or subsequent offense within one year is punishable by a fine not to exceed $\$ 100$ or imprisonment not exceeding six months or both. N.Y. Vehicle and Traffic Law (McKinney, 1952) \$\$86(1), 91(1) (not applicable to New York City). Penalties for violation of the state traffic commission's regulations concerning parking outside of a municipality are similarly limited, ibid. (McKinney, Supp., 1955) $§ 95 c(2)$ (6), except for the special situation provided for at ibid., \&58-a, which permits relatively higher penalties.
}

Violators of city speeding ordinances with regard to public highways may be fined not more than $\$ 100$ or imprisoned for thirty days, or both. Tbid. (McKinney, 1952) $\$ 56$ (excepting certain classes of cities which are perhaps governed by the limitations stated at ibid., $\$ 70[10]$ ). Violation of speeding regulations on state highways, ibid. (McKinney, Supp., 1955) $\$ 95-c(1)$, may be punished by a fine not to exceed $\$ 100$ or by imprisonment for not more than thirty days or both for the first offense; $\$ 50$ to $\$ 200$ or by imprisonment not more than ninety days or both for the second offense within eighteen months; and $\$ 100$ to $\$ 500$ or by imprisonment not exceeding 180 days or both for the third or subsequent offense committed within eighteen months. Ibid., at $\$ 56(4)$ and ibid. (McKinney, 1952) $\$ 70$ (4). Also, revocation of the driver's license would appear mandatory on the third offense. Ibid., at $\$ 71(2)$ (c).

It is important to note that some statutes creating vicarious liability for traffic violations specifically prohibit imprisonment of the owner. E.g., Alberta Rev. Stat. (1942) c. 275, $\$ 96$. Consult also note 60 infra.

Blanket discretionary power to penalize covering a wide range of traffic offenses would perhaps eliminate the distinction between speeding and parking offenses based on difference in possible penalties. E.g., Calif. Code Ann. (Deering, 1948) Vehicles $\$ 762$ ( $\$ 50$ and

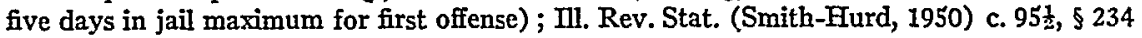
( $\$ 100$ maximum for first offense).

"II Ont. Rev. Stat. (1950) c. 167, $\$ 48$.

s2 Similar legislation has been enacted in other Canadian provinces. Consult B.C. Rev. Stat. (1936) c. 195, $\$ 74$ (construed in Rex v. Shannon [1946] 62 B.C.L.R. 557); Nova Scotia Rev. Stat. (1954) c. 184, 212 ; Man. Rev. Stat. (1940) c. 93, $\$ 48$; Alberta Rev. Stat. (1942) c. $275, \$ 96$. In England, 24 Halsbury's Statutes of England 658 (2d ed., 1950), the owner is guilty of an offense if he fails to give requested information as to the identity of the driver unless he can prove he is without knowledge thereof. 
have "interpreted" this legislation to require proof of some blameworthiness. ${ }^{33}$ Likewise, American due process would seem to require that responsibility for the acts of another in speeding offenses be based upon a power in the one punished to check the wrongdoer's activity, with cogent social reasons for its exercise. ${ }^{34}$ Finally, respect for the law might suffer by such a sacrifice of the principle of individual responsibility as would be involved in making an owner absolutely liable for all speeding offenses involving his vehicle. ${ }^{35}$

\section{Presumptive Owner-Operation}

The second and more common method of solving the operator-identification problem for parking offenses has been the establishment of owner-operator presumptions. State courts have generally upheld such statutory ${ }^{36}$ and judicial ${ }^{37}$ presumptions when applied to parking offenses. ${ }^{38}$

${ }^{33}$ See Regina ex rel. Collins v. Greenfield [1954] O.W.N. 292; Regina v. Curley [1953] O.W.N. 603. But see Canadian case cited in note 34 infra, coming to a contrary conclusion.

34 The only case yet found involving vicarious liability for speeding offenses comes to a conclusion contra that stated in text. The King v. Labbe, 17 Can. Cum. Cas. 417 (1910). It was there held that under the applicable Quebec statute the owner of an automobile may be convicted for a speeding violation committed with his vehicle while it was being driven, without consent, by a mechanic with whom it had been left for repairs. The owner "if he does not prevent his vehicle from passing into the control of persons who will violate the law with it ... is liable not for having committed a crime but liable pecuniarily for penalties attached to the violations. ..." Ibid., at 435.

${ }^{35}$ Professor Hall seriously questions whether compelling reasons can ever exist such as to justify the enactment of "public welfare" offenses which disregard the element of blameworthiness. It is his view that liability without regard to fault makes sense, if at all, only in tort law where reparation for damage caused by accident is allocated according to riskbearing ability, in absence of any more rational basis, because the cost of reparation must fall somewhere. Hall, General Principles of Criminal Law 290-92, 300-302 (1947).

${ }^{38}$ St. Louis v. Cook, 359 Mo. 270, 221 S.W. 2d 468 (1949) (ordinance) ; People v. Bigman, 38 Cal. App. 2d 773, 100 P. 2d 370 (Super. Ct., 1940) (statute); Commonwealth v. Kroger, 276 Ky. 20, 122 S.W. 2d 1006 (1938) (ordinance); People v. Kayne, 286 Mich. 571, 282 N.W. 248 (1938) (ordinance). But cf. Nasfell v. Ogden City, 249 P. 2d 507 (Utah, 1952) (holding ordinance invalid because municipality had no power, express, or implied, to establish rules of evidence); People v. Hoogy, 277 Mich. 578, 269 N.W. 605 (1936) (ordinance), discussed at page 548 infra. Consult $9 \mathrm{McQuillin}$, The Law of Municipal Corporations $\$ 27.45$ (3d ed., 1950), which represents the result in the Nasfell case as the general rule.

A typical regulation provides: "The presence of any vehicle in or upon any public street ... parking in violation of any ordinance ... shall be prima facie evidence that the person in whose name such vehicle is registered as owner committed or authorized the commission of such violation." "Nasfell v. Ogden City, supra, at 507.

${ }^{37}$ State v. Morgan, 72 R.I. 101, 48 A. $2 d 248$ (1946) (evenly divided court); People v. Rubin, 284 N.Y. 392, 31 N.E. 2d 501 (1940). Contra: State v. Scroggin, 236 N.C. 19, 72 S.E. 2d 54 (1952), noted in 39 Va. L. Rev. 239 (1953), refusing to extend presumption applicable in civil cases to parking violation because regulation of traffic offenses was for legislature.

${ }^{38}$ For summaries, consult Wilson, Prima Facie Evidence in Parking Violation Cases, 17 N.I.M.L.O. Mun. L. Rev. 296 (1954) ; 39 Va. L. Rev. 239 (1953), noting State v. Scroggin, 236 N.C. 19, 72 S.E. 2d 54 (1952); and Levin, Ownership as Evidence of Responsibility for Parking Violations, 41 J. Crim. L. \& Criminology 61 (1950).

Although "operation" is not involved in the commission of a parking offense, the term 
In at least two jurisdictions the statutory owner-operator presumptions pertain to traffic offenses generally, ${ }^{39}$ although their application to speeding violations has never been tested. But recently in People v. Hildebrandt $t^{40}$ the New York Court of Appeals in a four-three decision refused to extend to a speeding offense the judicial presumption approved for parking violations in People v. Rubin.11 The court, per Judge Desmond, maintained (1) that there were important differences between parking and speeding violations which should operate to limit the application of an owner-operator presumption to the former, and (2) that such a presumption extended to speeding offenses would raise a serious question of due process which requires in criminal cases a natural or rational connection between proven facts and the presumed fact. ${ }^{42}$ In any event it was for the legislature, not the judiciary, to make rules for traffic control.43

The United States Supreme Court in Tot v. United States ${ }^{44}$ enunciated the "rational connection" standard as the sole and necessary criterion for determining the validity under the due process clause of a statutory presumption. ${ }^{45}$ Although the language in Tot is ambiguous, ${ }^{46}$ Professor McCormick

will be used herein to denote those acts which give rise to the parking violation. Thus, a presumption that the owner committed these acts will be referred to throughout as an owner-operator presumption.

${ }^{30}$ The statutory presumption in Pennsylvania, enacted in 1929 , is completely unrestricted. $75 \mathrm{~Pa}$. Stat. Ann. (Purdon, 1953) $\$ 739$. See discussion at page 548 infra. In Connecticut the presumption, established in 1953, applies to a number of infractions, including speeding. Conn. Pub. Acts (1953) No. 327.

10308 N.Y. 397, 126 N.E. $2 d 377$ (1955), discussed at page 533 supra.

1284 N.X. 392, 31 N.E. 2d 501 (1940). This decision upheld the extension of the judicial presumption of owner-operation applied in civil cases in New York to a charge of illegal parking. The appellate decision sanctioned the extension in People v. Marchetti, 154 Misc. 147, 276 N.X. Supp. 708 (1st Dep't, 1934). Consult also note 61 infra.

${ }^{62}$ See Tot v. United States, 319 U.S. 463 (1943) ; People v. Terra, 303 N.Y. 332, 102 N.E. 2d 576 (1951).

${ }^{43}$ Accord: State v. Scroggin, 236 N.C. 19, 72 S.E. $2 d 54$ (1952), refusing to extend civil presumption to parking violations.

4319 U.S. 463 (1943).

${ }^{65}$ The Supreme Court said that a rational connection and comparative convenience of producing evidence of ultimate fact "are not independent tests but that the first is controlling and the second but a corollary." Ibid., at 467.

For criticism of the "rational connection" as a constitutional necessity consult McCormick, Evidence $\$ 313$ (passim) (1954); 4 Wigmore, Evidence $\$ 1356(\mathrm{~b})$ (3d ed., 1940); Morgan, Federal Constitutional Limitations upon Presumptions Created by State Legislation, Harvard Legal Essays 323 (1934). A standard based strictly on rational connection is not, however, consistently followed, even by the Supreme Court. See United States v. Fleischman, 339 U.S. 349 (1950), where the burden of producing evidence was held to have been properly shifted to the defendant on the basis of her superior access to the evidence. McCormick suggests that the trend in state cases at least seems to be toward an emphasis 
interprets this standard as generally meaning that "the court has only to ask: ... can we say ... that the legislature could not reasonably have believed that this inference is more probable than not?"47 While the New York Court of Appeals has consistently applied the "rational connection" test, its decisions do not seem to require that the inference be "more probable than not." The Hildebrandt court said there must be a "natural, not an unreasonable or unnatural, connection with facts proven." $\$ 48$ Language even less strict can be found in the earlier decisions relied on. ${ }^{49}$ No decision was cited by the New York Court of Appeals-nor has any other case been found-which vitiates a lower court's presumption or inference for lack of a "rational connection."

The court in the Hildebrandt case, although reserving opinion on whether a statutory presumption of owner-operation would be valid under this test, ${ }^{51}$ indicated that a statutory owner-operator presumption might not meet the test of probability laid down in the Tot case by holding that it was not permissible for the trial judge to infer operation by its owner from the mere identification of the automobile. ${ }^{52}$ The court declared:

on fundamental fairness rather than conformity with traditional criminal procedures. McCormick, Evidence $\$ 313$, at 662 n. 33 (1954).

so "Under our decisions, a statutory presumption cannot be sustained if there be no rational connection between the fact proved and the ultimate fact presumed, if the inference of the one from proof of the other is arbitrary because of lack of connection between the two in common experience. ... Whether the statute in question be treated as expressing the normal balance of probability, or as laying down a rule of comparative convenience in the production of evidence, it leaves the jury free to act on the presumption alone once the specified facts are proved, unless the defendant comes forward with opposing evidence. And this we think enough to vitiate the statutory [presumption]." (Italics added.) 319 U.S. 463, 467, 469 (1943).

${ }^{47}$ McCormick, Evidence $\$ 313$, at 660 (1954).

${ }^{48}$ People v. Hildebrandt, 308 N.Y. 397, 400, 126 N.E. 2d 377, 378 (1955).

${ }^{40}$ In People v. Terra, 303 N.Y. 332, 335, 102 N.E. 2d 576, 578 (1951), the court quoted in part the following language from People v. Cannon, 139 N.Y. $32,43,34$ N.E. 759,762 (1893): "The limitations [upon the creation of criminal statutory presumptions] are that the fact upon which the presumption is to rest must have some fair relation to, or natural connection with the main fact. The inference of the existence of the main fact because of the existence of the fact actually proved, must not be merely and purely arbitrary, or wholly unreasonable, unnatural or extraordinary. . . ." In People v. Pieri, 269 N.X. 315, 324, 199 N.E. 495, 498 (1936), the court posed the question: "Is this an unreasonable or unnatural presumption? Is there not here some rational relation between the fact proved and the fact presumed?" Professor McCormick has interpreted the Terra case-with some justificationas deviating from the rational connection standard and relying on the more flexible formula of Morrison v. California (see note 64 infra). McCormick, Evidence $\$ 313$, at 663 (1954).

${ }^{50}$ Professor Morgan observed that "[t]hus far [1943] no presumption created by judicial decision has been thus condemned." Morgan, Further Observations on Presumptions, 16 So. Cal. L. Rev. 245, 259 (1943). Nor has research uncovered any such instance since 1943 aside from the Hildebrandt case.

"1 308 N.Y. 397, 400, 126 N.E. 2d 377, 379 (1955). "We express no advance opinion as to the validity of [the asserted presumption in statutory form] if one should be enacted."

${ }^{52}$ The court viewed the "presumption" in criminal cases as a rule of law attaching definite probative value to a specific fact; the "inference" is a permissive conclusion by a trier of 
We all know that many a passenger car is customarily driven at various times by various persons, we know that many a person owns more than one passenger automobile, we know that some owners are not licensed operators, and we are informed that there are outstanding in this State at least one million more automobile operators' licenses than passenger automobile registrations. From all of that it follows, we think, that it is hardly a normal or ready inference or deduction that an automobile which speeds along a highway is being driven by its owner, and by no other person. ${ }^{\mathbf{5 3}}$

Reasonable men may differ with the court's general conclusion that to infer operation by the owner would not be a "normal or ready inference"-much less an "unnatural" one. Reliable statistics indicate that about seventy per cent of all licensed drivers in the United States are car owners. ${ }^{54}$ Several complicating factors, it is true, cannot be ascertained: the number of unlicensed drivers, the extent to which car owners drive cars owned by others, the comparative amount of driving by the average car owner and the average nonowner driver, and whether owners are more or less inclined to speed than nonowners. Still, it may reasonably be assumed that these factors more or less offset each other and, on the average, for something over half the total speeding time of each car the owner is the operator. And in any event, as the dissenting opinion emphasized, the probabilities of owner-operation cannot be said to be substantially different as between speeding and parking situations.

Whether we use the label "presumption" or "inference," it would seem indisputable that stare decisis compels affirmance. . . . [We may not] disregard the Rubin decision . . . because there are in this state more licensed drivers than cars. It is, nevertheless, as likely that the owner will be at the wheel of his car when it speeds as when it parks. ${ }^{55}$

In distinguishing the speeding from the parking offense for purposes of applying an owner-operator presumption, the New York Court of Appeals

the facts, unaided by any rule or theory of law directly applicable. Ibid., at 400,378 . In practice this distinction is minimized by the fact that presumptions against criminal defendants are treated as "permissive" rather than "mandatory" upon the trier of fact. People v. Terra, 303 N.Y. 332, 337, 102 N.E. 2d 576, 580 (1951) ; People v. Cannon, 139 N.Y. 32, 43-44, 34 N.E. 759, 763-64 (1893). Consult generally McCormick, Evidence $\$ 308$ (1954). But a valid statutory presumption may be created upon a view of relation broader than a jury might take in a specific case. See Tot v. United States, 319 U.S. 463, 468 (1943). And, of course, a legislature and a court might differ as to what is a permissible inference.

${ }^{53} 308$ N.Y. 397, 401, 126 N.E. 2d 377, 379 (1955). In People v. Rubin a unanimous court had said: "To rule that this inference [of owner-operation in parking offenses] may not be drawn ... would be to deny to the trier of the facts the right to use a common process of reasoning." 284 N.Y. 392, 396, 31 N.E. 2d 501, 502 (1940).

"According to Automobile Facts and Figures (Automobile Manufacturers' Association, 1954), in 1953 the total number of licensed automobile drivers in the United States was about 57.8 million (p. 38), and the total number of car registrations, about 46.3 million (p. 24). Only about twelve per cent of all owners owned more than one car (p. 34), making the number of owners about 41 million.

${ }^{55} 308$ N.Y. 397, 402-3, 126 N.E. 2d 377, 380 (1955). 
seemed to attribute some significance to the fact that in the latter case the car is commonly unattended. ${ }^{56}$ But the court found a seemingly more essential difference in the nature of the offenses. A parking violation could be considered as merely a wrongful storage of a vehicle on public property for which it is not unreasonable to charge the owner. ${ }^{57}$ Speeding, on the other hand, "is personal, individual wrongdoing, which can subject the wrongdoer to serious penalties. . . . Such 'traffic infractions' . . . are tried like misdemeanors ... and to them ... there should be applicable the criminal-law rules of presumption of innocence and necessity of proof beyond a reasonable doubt." is much higher than the normal "fee" for parking or any amount justifiable by a quasi-contract theory, and the fact that the owner may escape liability by rebutting the presumption of operation both suggest that the purpose of the parking prohibition, as in the offense of speeding, is not to compensate the municipality, but to discourage undesirable activity.

Quite probably it was the difference in penalties ${ }^{59}$ which best accounts for the refusal of the majority in the Hildebrandt case to sanction the presumption. The courts often weigh heavily the factor of severity of penalty in determining whether a given proceeding is "criminal" or "civil" in nature. ${ }^{60}$ And if parking fines be considered only in the nature of civil penalties, the $R u b i n$ case affords no authority for the extension of an owner-operator presumption to "crimes."

${ }^{56}$ Ibid., at $401,379$.

${ }^{67}$ Ibid. The two considerations together purportedly made parking violations "of a special sort." It was the dissent's position that "[t]he regulation involved in the $R u b i n$ case was in no sense an 'in rem' provision, directed against the car itself, but was aimed at the individual who actually parked it; thus, the regulation provided, in so many words, that 'No person shall park a vehicle' for more than one hour in certain streets." Ibid., at 402 n. 1, 380 n. 1.

${ }^{58}$ Ibid., at 399-400, 378. See the New York statute, quoted in note 1 supra.

${ }^{60}$ Consult note 30 supra.

${ }^{\infty 0}$ Where there is a power to imprison, the proceedings are criminal in nature, Unger $v$. Fanwood, 69 N.J.L. 548 (S. Ct., 1903) (violation of speed ordinance), and rules of evidence applicable to criminal cases should be applied, Barron v. Anniston, 157 Ala. 399, 48 So. 58 (1908). Consult Public Torts, 35 Harv. L. Rev. 462 (1922), wherein it is suggested that the sole question to be asked regarding whether violation of a police regulation is a "public tort" or a "real crime" is whether the legislative body intended the penalty to be compensation or punishment; where imprisonment is permitted it is submitted that the latter is clearly the case. Consult generally 9 McQuillin, The Law of Municipal Corporations $\$ \$ 27.06$, 27.45 (3d ed., 1950).

In the Hildebrandt case, there was only a "small fine" imposed. People v. Hildebrandt, 308 N.Y. $397,399,126$ N.E. 2 d 377, 378 (1955). Reasonableness is to be tested by the penalty which may be imposed, not that which actually is imposed. Cf., e.g., Commonwealth v. Diaz, 326 Mass. 525, 95 N.E. 2d 666 (1950).

${ }^{2}$ In the Rubin case the court did not characterize the offense or the nature of the proceedings as between "civil" or "criminal." The question was initially presented to a New York review court in City of Buffalo v. Thorpe, 132 Misc. 307, 230 N.Y. Supp. 187 (S. Ct., 1928). The court sanctioned the presumption on the theory that an action brought in the 
"[S]peeding itself is sometimes a misdemeanor . . . and . . . the 'presumption' of identity here indulged in would, for consistency, have to be made available in prosecutions for misdemeanors, and even felonies, committed in the operation of automobiles. . .."

A statutory owner-operator presumption could of course be confined to speeding and lesser offenses. It is likely that such a presumption would generally be upheld even if it be conceded that it relaxes somewhat the "rational connection" standard. ${ }^{63}$ Certainly the presumption has a considerable basis in probability, and essential fairness does not seem impaired where the charge is not a serious one and the facts are more easily accessible to the defendant. ${ }^{64}$ As Wigmore has emphasized, the presumption is designed chiefly to regulate and facilitate the process of proof; ${ }^{65}$ it does not relieve the prosecution of its traditionally severe burden of persuasion. ${ }^{66}$ Finally, an owner-operator presumption might well aid in the more efficient administration of the traffic laws.

Since the judge, or magistrate, is practically always the trier of fact it might appear unduly theoretical to consider such matters as the amount of evidence necessary to rebut an owner-operator presumption for traffic infractions. Nonetheless, the question is not without its troublesome aspects. For

name of the city (rather than the people of New York) for violation of a parking ordinance was a "civil action." The fine imposed was five dollars. Professor McCormick, a critic of the "rational connection" test as a sole and necessary criterion for the validity of statutory presumptions, concedes that there is a due process argument for a stricter standard in criminal cases. McCormick, Evidence $\$ 313$, at 661 (1954).

${ }^{62}$ People v. Hildebrandt, 308 N.Y. 397, 400, 126 N.E. 2d 377, 378 (1955). The court is referring to speeding on the thruway. N.Y. Public Authorities Law (McKinney, 1952) $\$ 361(1)$. But see the New York statute quoted at note 1 supra.

"For indications that the "rational connection" standard does not rest on sturdy ground, see sources cited at note 45 supra. Of course, the proceedings might be characterized as "civil," although it seems unwise to make the issue turn on a mere label.

a These considerations are included in the flexible formula advanced by $\mathrm{Mr}$. Justice Cardozo in Morrison v. California, 291 U.S. 82, 91 (1933), and the point of superior access was held to justify shifting the burden of producing evidence to the defendant in United States v. Fleischman, 339 U.S. 349 (1950). Another test sometimes used-the "greater includes the less"--looks at whether the legislature could have imposed liability not conditioned by the fact presumed. See Ferry v. Ramsey, 277 U.S. 88 (1928) (civil liability). In view of what is concluded in Part I of this comment, this test would not appear to be helpful here.

${ }^{05} 4$ Wigmore, Evidence $\$ 1356$, at 724 (3d ed., 1940).

${ }^{\infty}$ If the proceedings be considered "criminal," theoretically the presumptive device will not relieve the prosecution of its burden of proving guilt beyond a reasonable doubt. The unrebutted presumption serves only to carry the case to the triers of fact with the state reacquiring upon rebuttal its burden of avoiding a directed verdict against it. E.g., People v. Terra, 303 N.Y. 332, 337, 102 N.E. 2d 576, 580 (1951). Consult generally Brosman, The Statutory Presumption, 5 Tulane L. Rev. 178, 196-97 (1931); Alexander, Presumptions in Criminal Cases, 17 Miss. L. J. 45, 57-58 (1945). In the trial of traffic offenses, of course, a judge or a magistrate is almost always the trier of fact. See, e.g., N.Y. Vehicle and Traffic Law (McKinney, Supp., 1955) $\$ 2(29)$. Consult Warren, Traffic Courts 76 (1942). 
example, the Pennsylvania statute, which alone touches on rebuttal, provides that the presumption shall be overcome if the defendant testifies under oath that he was not the operator at the time of violation and submits himself to an examination as to the operator. ${ }^{67} \mathrm{~A}$ similar parking ordinance was held invalid in People v. Hoogy ${ }^{68}$ as infringing the privilege against self-incrimination. ${ }^{69}$ Thus, paradoxically, legislative provision for ease of rebuttal may result in invalidation of the basic statute. In the absence of such a provision, however, it may indeed be difficult to rebut the presumption. ${ }^{70}$

This reluctance of the New York Court of Appeals to sanction the creation of a judicial presumption of owner-operation in the commission of a traffic offense which is "sometimes a misdemeanor" is understandable. Judicial presumptions against criminal defendants in "public welfare" offenses are rare

${ }^{67} \mathrm{~Pa}$. Stat. Ann. (Purdon, 1953) $\$ 739$. Compare English and Canadian legislation, note 32 supra. In Commonwealth v. Foulke, $22 \mathrm{~Pa}$. Dist. \& Co. 135 (1935) the court stated the statute did not represent a denial of due process, but made no mention of the selfincrimination problem. It was held that the presumption could not be applied where there was only circumstantial evidence of the involved car. More recently, the statute was applied to improper operation in Franke Appeal, 75 Pa. Dist. \& Co. 408 (1950).

${ }^{68} 277$ Mich. 578, 269 N.W. 605 (1936) (citing no authority).

${ }^{\infty}$ This defense to a statutory presumption is rarely effective. Brosman, in an extensive 1930-31 review of statutory presumptions, maintained that state decisions "uniformly dismiss the objection." Brosman, The Statutory Presumption, 5 Tulane $I$. Rev. 17, 178, 182 (1930). A leading Supreme Court case is Yee Hem v. United States, 268 U.S. 178 (1925). Nonetheless, the objection has some technical merit where practically speaking the presumption can be overcome only by the accused taking the stand.

${ }^{70}$ The question of rebuttal has not yet arisen since the defendant owner typically introduces no rebuttal evidence. In the absence of rebuttal evidence, it is clear that the prosecution's case is sufficient to go to the trier of fact. McCormick, Evidence $\$ \S 308,310$ (1954). And if the presumption be deemed mandatory (instead of merely permissive), the trier is conclusively bound by the fact presumed. 9 Wigmore, Evidence $\$ 2490$ (3d ed., 1940) (stating that all presumptions should have this effect in the absence of rebuttal evidence).

The quantum of evidence necessary to rebut a statutory presumption is unclear. Under one view, the presumption should "continue to operate unless and until the evidence persuades the trier at least that the non-existence of the presumed fact is as probable as its existence." Morgan, Instructing the Jury upon Presumptions and Burden of Proof, 47 Harv. L. Rev. 59, 83 (1933). Another view states that "if the opponent does offer evidence to the contrary (sufficient to satisfy the judge's requirement of some evidence), the presumption disappears as a rule of law. . . ." Wigmore, supra, $\$ 2491$ (2), at 289. However, if, as suggested by Morgan, Some Observations Concerning Presumptions, 44 Harv. L. Rev. 906, 931 (1931), the consequences of a presumption be based upon the reasons which justify its existence, the courts may require more than a mere denial for rebuttal of the owneroperator presumption. This would be in harmony with the probability, procedural convenience, superior means of access and public interest discussed in text supra as justifying this presumption.

It must also be noted that the type of evidence needed for rebuttal will depend upon the particular statute involved. Typically, rebuttal would necessarily include more than evidence of non-operation, since the owner is also presumed to have "authorized" the violation. See authorities cited in note supra. Consult also McCormick, supra, $\$ 311$, at $651-52$ discussing the rebuttal problem in civil vehicle prosecution cases which has proved troublesome. 
enough; a judicial presumption which would infer the identity of the lawbreaker is probably without precedent. Yet had the presumption challenged in Hildebrandt been a statutory creation it is possible that the result would not have been different. Aside from the court's appraisal of the probabilities of owner-operation the majority may have been influenced by inarticulated notions regarding the need and desirability of mitigating the burden of direct proof of operation where more serious traffic infractions are involved.

A refusal to extend an owner-operation presumption to this area may reflect a judicial appraisal that there exists no pressing social need for it and that, quite the contrary, dangerous vehicle operation should not only be detected but actively policed and controlled. Although catching speeders is expensive, its virtues are obvious. ${ }^{71}$ In this regard, it may be noted that extensive use of the phototraffic camera would seriously contract the extra-legal pardoning power now exercised by enforcement officers-perhaps a mixed blessing. ${ }^{72}$ Secondly, it may be difficult to limit the operation of the presumption to proven facts which are largely the product of mechanical devices which diminish the likelihood of error in identification of the vehicle. Finally, a court is likely to be influenced by its fears regarding abuse and incompetence at the enforcement level. Certainly the inconvenience, delay, and relative expense in attempting rebuttal (much less appeal) may well encourage the owner to submit without protest to the imposition of an unjustified penalty; to this extent, then, an owner-operator presumption would operate as a strict owner-liability system.

To this last objection there are counter-considerations which argue for the creation of an owner-operator presumption. It is probable that in a high majority of traffic offenses in which the owner is not the offender, as the head of the household he nonetheless ultimately suffers the cost of the penalty. And in many other situations where he did not offend he would not be financially prejudiced in submitting to the penalty as it may be supposed that he would have informal means of recourse, as with an employee, or would simply be reimbursed according to the amenities, as with an employee or friend. Of course he would not be completely spared whatever embarrassment or loss of reputation might be involved in submitting to the charge in these situations. The remaining occasions of non-owner operation would be rare, and rebuttal could be facilitated by a requirement of early notice to the owner added to a light burden of coming forward with rebuttal evidence.

\footnotetext{
${ }^{71}$ But see the dissenting opinion in People v. Hildebrandt, 308 N.Y. 397, 402, 126 N.E. 2d 377,379 (1955), which considers the perils of the chase.

${ }^{72}$ For judicial recognition of this pardoning power see Application of Blackburn, 206 Misc. 393, 401, 134 N.Y.S. 2d 138, 146 (S. Ct., 1954). As to the "fix" consult Warren, Traffic Courts, c. X (1942).
} 